\title{
Field trials of different traps for malaria vectors and epidemiological investigations at a foot-hill basin in Kanchanaburi, Thailand*
}

\author{
Somjai Leemingsawat ** \\ Department of Medical Zoology, St. Marianna University, \\ Miyamae-ku, Kawasaki 213, Japan
}

(Received: July 27, 1988)

Key words: malaria endemicity, vector prevalence, response, wing-sound, breeding site.

\begin{abstract}
Malaria endemicity and the vector prevalence were investigated by using biting collections and trapping systems at a foot-hill malaria endemic area in Kanchanaburi, Thailand. A breeding basin, a stream-bed in a village Ban Tha Lam Yai, was selected as the study area. The buffalo bait caught the highest number of species (16 species) and individuals of anopheline mosquitoes; the number of individuals was 4 times more Anopheles minimus and 3 times more An. maculatus than that with the human bait. High parous rates of the two vectors throughout the year, 50\% in September and 90\% in May for An. minimus, $43 \%$ in October and $74 \%$ in March for An. maculatus, seemed to be participating in high infection rates of them and the stability of malaria endemicity in the village. The vectors were efficiently attracted to sound traps when those were combined with a hamster and dry ice. The number of vectors trapped was 3 times more than that with the human bait, but nearly a half of that with the buffalo bait. Sound traps segregated $A n$. minimus into two groups according to the attractiveness at different sound frequency: one was $500-600 \mathrm{~Hz}$ and another was $800-1,000 \mathrm{~Hz}$. An. maculatus was, however, attracted with a similar pattern to every frequency range from 350 to $800 \mathrm{~Hz}$.
\end{abstract}

\section{INTRODUCTION}

Among anopheline mosquitoes, Anopheles dirus, An. maculatus and An. minimus have been known as principal vectors of human malaria in Thailand. For decades, malaria control in Thailand has been carried out by using insecticide residual spray. This method has raised insecticide resistance in the vectors, and health hazards including environmental pollution, toxic side-effects and a high inci-
* This study was financially supported partially by grants-in-Aid (No. 61041079, No. 62043075 and No. 01044130) for Overseas Scientific Research from the Ministry of Education, Science and Culture of Japan and partially by a collaborative Research Project grant from PRO/WHO to the Collaborating Centre for Research and
Training in Vector Genetics of Mosquito and other Arthropods of Health Importance.

** Present address: Department of Medical Entomology, Faculty of Tropical Medicine, Mahidol University 420/6 Rajvithi Road Bangkok 10400, Thailand. 
dence of destruction of non-target organisms have also resulted. Efforts have been made to develop other control methods, such as physical and biological methods (Ismail, 1983; Malaria Division, 1985). In malaria vector investigation a survey on population dynamics, actual transmission data on the malaria vectors and the human bait method are still being used, but there has been no improvement in results. Because the operation of this method poses major hazards for malaria workers, less hazardous methods have been sought. Recently a trap using artificial wingbeat sound has been proved to be an effective technique for trapping males of Culicine and Mansonia (Ikeshoji, 1985; Ikeshoji et al., 1985; Kanda et al., 1987, 1988). Furthermore, the success of sound trapping of females of these species was also reported (Kanda et al., 1987; Leemingsawat et al., 1988 ), the efficacy of this sound trap system has been demonstrated with genus Mansonia, vector of filariasis by Kanda et al. (1988), and with Culex tritaeniorhynchus, vector of Japanese encephalitis (Thongrungkiat, unpublished). The present study was designed to select a malaria endemic area as the study site to reveal the epidemiological background, such as the parasite rate in the community, vectorial population dynamics and habitat. The physio-ecological characteristics of these vectors were utilized to apply the attraction to a sound trap system to their surveys and control. Thus, the present paper reports that use of the sound trapping collection method demonstrated its efficacy in monitoring population dynamics in comparison with bait traps and in proving the possibilities for reduction of the mosquito density of malaria vectors, An. minimus and An. maculatus in the study site.

\section{Materials and Methods}

The selected study site is the stream-bed of a foot-hill basin (Fig. 1) in a village with a population of 1,773. The village, Ban Tha Lum Yai, $2 \mathrm{~km}$ distant from Ratanakosin Reservation Park, is a known endemic area of human malaria in Kanchanaburi (Malaria Division, 1986-1987). Major crops in the village are maize and sugar-cane, and cattle are raised for farm work. Houses are scat- tered along a creek which runs through the middle of the village. The study was carried out from February 1987 to January 1988.

Blood survey. Malariometric active case detection was performed by examining blood smear of malaria cases or of people with malaria-like symptoms, to find out the malaria incidence in the village.

Mosquito collection. 1) Human and animal baits: The buffalo bait trap was performed using the same buffalo bait trap for two consecutive nights at intervals of approximately 30 days, to know the seasonal prevalence, to compare with other trapping methods, and to know population dynamics as suggested from their physiological age at the stream-bed, the main breeding site of the malaria vectors in the village. A part of the female anopheline vectors collected by the buffalo bait were dissected for evaluation of the parous rates in relation to mosquito longevity. Living baits of both human and animals (buffalo, dog, hamster and chicken) were used to know the host preference of anopheline mosquitoes and also to compare the efficacy of mosquito collection among other trapping methods. In bait collection with a buffalo, a mosquito net trap described by Kanda (1979) (Fig. 2) was used. The other animal bait trappings were carried out by adopting the same ones described by Sucharit and Supavej (1987). In these human bait and animal bait trappings, two of each animal were fixed side by side at about $50 \mathrm{~m}$ intervals at the stream-bed for 2 consecutive nights at the end of January 1988. Outdoor human bait trapping was performed on two men at the stream-bed, $50 \mathrm{~m}$ apart, by biting catch collection during September 1987 to January 1988.

2) Sound traps: Two types of modified sound traps (cage and cylinder traps) designed by Kanda et al. (1988) (Figs. 3 and 4) were used to compare their attractiveness. One with various frequencies of wingbeat sound was also used. These sound traps combined with a hamster and dry ice (Kanda et al., 1988) were set at fixed sites in the stream-bed (Fig. 1) with the sound traps alternately emitting different wingbeat frequencies in their respective operation. All the sound traps were set from 6:00 p.m. to 6:00 a.m. for two consecutive nights. They 


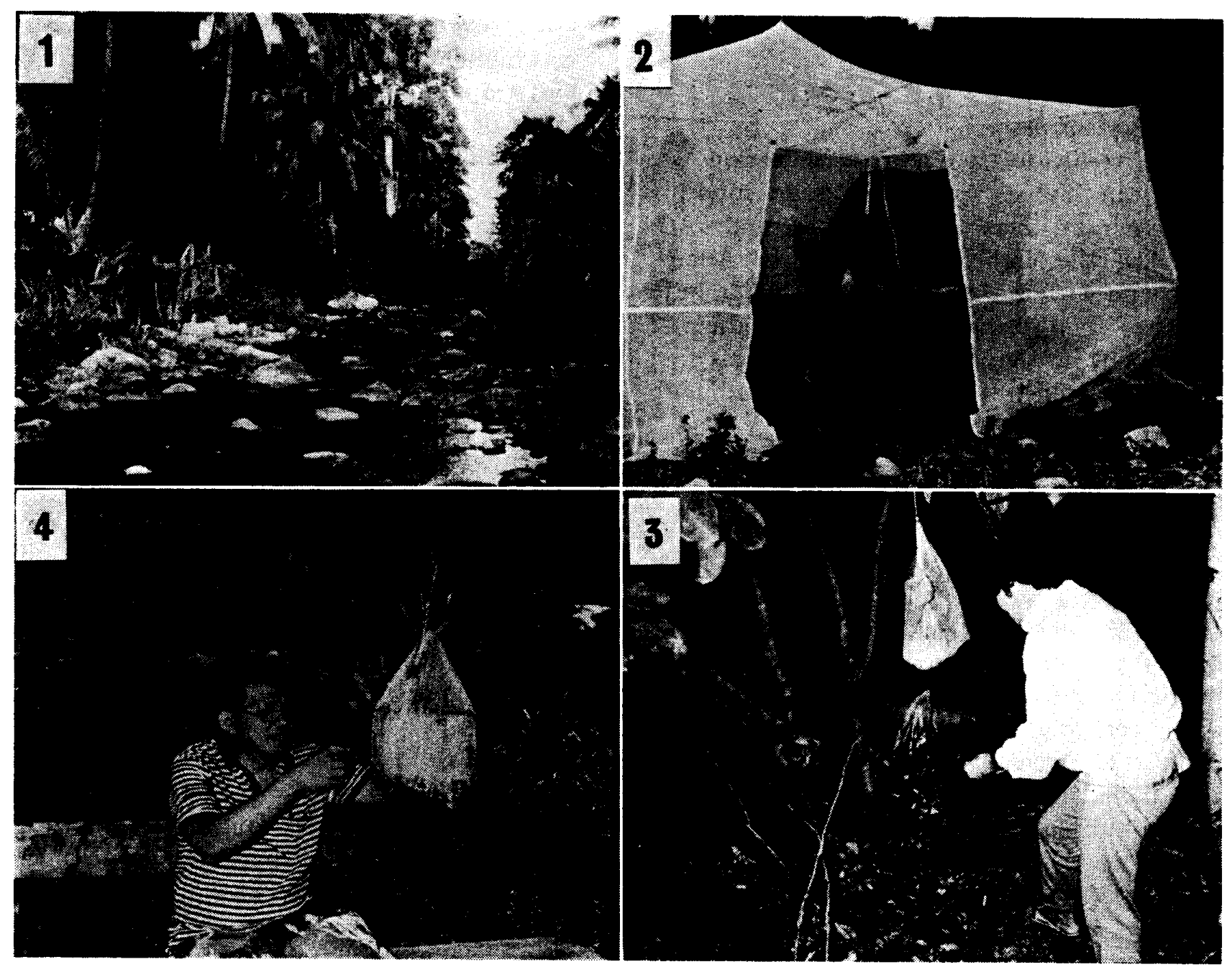

Fig. 1 Study site, a basin in Ban Tha Lam Yai, Kanchanaburi Province.

Fig. 2 Buffalo bait trapping, a buffalo covered with a mosquito net as animal bait.

Fig. 3 Setting a sound trap connecting cylinder and cage (see text).

Fig. 4 Counting and identification of mosquitoes trapped (identification is tentative).

were at a height of $0.5 \mathrm{~m}$ above the ground in the shade of a bush or low tropical tree at $30 \mathrm{~m}$ intervals along the stream-bed (Figs. 1 and 3 ). Sound was emitted under the conditions described by Kanda et al. (1988). A soundless control trap was also set similarly without a soundspeaker.

Comparison was made of the efficacy of the four different systems of traps with two each of buffalo bait and human bait at the study site in the same night in March and August, 1987. Response of female mosquitoes to the two types of trapping systems (cage type and cylinder one) emitting various frequencies of sound with dry ice and hamster was tested by using 2 traps of each for two consecutive nights in August 1987 (Table 7). In view of the higher trapping efficacy among various sound traps, four cage-type sound trap systems, respectively emitting 500,600 , 700,800 and $1,000 \mathrm{~Hz}$ of wing sound frequencies, were tested for the response of $A n$. maculatus and An. minimus at the same site for two consecutive nights around each month-end from March 1987 to January 1988.

3) Mosquito counting and identification: All mosquitoes collected were counted, identified with hand lens (Fig. 4) and recorded on the following day. Identification of $A n$. maculatus group was made according to the key of Rattanarithikul and Green (1986). 


\section{Results}

\section{Blood survey}

The results of active case detection are shown in Table 1. The average monthly positive rates were $29 \%$ in 1986 and $24 \%$ in 1987, the highest were $40 \%$ in August 1986 and $41 \%$ in December 1987. The data indicate high parasite rate during these 2 years with no significant decrease. This fact suggested epidemiological stability and high endemicity of malaria.

\section{Mosquito surveys}

Monthly prevalence of anopheline mosquitoes was surveyed by buffalo bait trappings from February 1987 to January 1988 (Table 2), and 16 species of Anopheles were collected. Among these species the principal malaria vectors, An. maculatus and An. minimus, were highly abundant, especially from August to November. The parous rates of An. maculatus and An. minimus collected from a buffalo bait trap are shown in Table 3. The rates were high throughout the period, ranging 50 to $90 \%$ in $A n$. minimus and 43 to $74 \%$ in $A n$. maculatus. Slightly lower rates were observed in September, October and November when the mosquito density was higher (Table 2). In addition to buffalo bait traps in the village, the relative importance of all suspected blood donors: human, $\mathrm{dog}$, chicken and hamster, were used for bait traps by simultaneous catch at the streambed. The results of simultaneous bait traps are shown in Table 4. An. minimus fed on all the baits tested, and An. maculatus bit 4 kinds of baits except for chicken. But other species did not bite any bait except buffalo. This result indicates that buffalo may be the main blood donor to the vectors; human, a partial donor and dog, to a lesser extent. Similarly, only An. maculatus and An. minimus were attracted to human bait according to data obtained from September 1987 to January 1988 (Table 5). Thus, it is strongly suggested these two species are the principal vectors in the village. Among 3 forms of An. maculatus, A, B and $\mathrm{G}$, form A was most abundant.

Comparison of effectiveness of various collection methods is shown in Table 6. A buffalo bait trap and a sound trap combined with dry ice and a hamster were highly effective out of 9 kinds of traps tested. Response to various frequencies of wingbeat sound and type of trap systems, (cage type

Table 1 Number of malaria parasite positive cases among the community at Ban Tha Lum Yai, Kanchanaburi, in 1986 and 1987.

\begin{tabular}{|c|c|c|c|c|c|c|c|c|c|c|}
\hline \multicolumn{6}{|c|}{1986} & \multicolumn{5}{|c|}{1987} \\
\hline Month & $\begin{array}{l}\text { No. } \\
\text { exam. }\end{array}$ & $\begin{array}{l}\text { No. } \\
\text { posit. }\end{array}$ & P.f. & P.v. & $\begin{array}{c}\text { Posit. } \\
\text { rate }\end{array}$ & $\begin{array}{l}\text { No. } \\
\text { exam. }\end{array}$ & $\begin{array}{l}\text { No. } \\
\text { posit. }\end{array}$ & P.f. & P.v. & $\begin{array}{l}\text { Posit. } \\
\text { rate }\end{array}$ \\
\hline Jan. & 279 & 80 & 39 & 41 & 0.29 & 187 & 51 & 18 & 33 & 0.27 \\
\hline Feb. & 196 & 41 & 26 & 15 & 0.21 & 160 & 38 & 5 & 33 & 0.24 \\
\hline Mar. & 179 & 34 & 21 & 13 & 0.19 & 112 & 30 & 9 & 21 & 0.27 \\
\hline Apr. & 169 & 26 & 18 & 8 & 0.15 & 145 & 45 & 16 & 29 & 0.31 \\
\hline May & 282 & 85 & 28 & 57 & 0.30 & 252 & 47 & 24 & 23 & 0.19 \\
\hline Jun. & 333 & 84 & 43 & 41 & 0.25 & 530 & 112 & 60 & 52 & 0.21 \\
\hline Jul. & 455 & 158 & 95 & 63 & 0.35 & 591 & 115 & 74 & 41 & 0.19 \\
\hline Aug. & 490 & 198 & 140 & 58 & 0.40 & 428 & 97 & 45 & 52 & 0.23 \\
\hline Sept. & 437 & 165 & 109 & 56 & 0.38 & 591 & 115 & 74 & 41 & 0.19 \\
\hline Oct. & 366 & 121 & 76 & 45 & 0.33 & 381 & 57 & 22 & 35 & 0.15 \\
\hline Nov. & 236 & 78 & 38 & 40 & 0.33 & 556 & 148 & 84 & 64 & 0.27 \\
\hline Dec. & 193 & 61 & 26 & 35 & 0.32 & 195 & 80 & 38 & 42 & 0.41 \\
\hline Mean & 301.2 & 94.3 & 54.9 & 39.3 & 0.29 & 344.0 & 77.9 & 39.1 & 38.8 & 0.24 \\
\hline
\end{tabular}

P.f., Plasmodium falicparum; P.v., Plasmodium vivax. 
Table 2 Number of Anopheles collected with buffalo bait traps in Ban Tha Lum Yai, Sri-Sawat, Kanchanaburi, from Feb. 1987 to Jan. 1988.

\begin{tabular}{|c|c|c|c|c|c|c|c|c|c|}
\hline Anopheles & Feb. & Mar. & May & Aug. & Sept. & Oct. & Nov. & Dec. & Jan. \\
\hline aconitus & 1 & & & & & & 5 & 3 & 3 \\
\hline barbirostris & 7 & 32 & 6 & 1 & 1 & & 3 & 2 & 21 \\
\hline culicifacies & & 7 & 14 & 78 & 154 & & & & 1 \\
\hline dirus & & & & & 1 & 1 & & & \\
\hline kochi & & 10 & & & 11 & 42 & 221 & & 7 \\
\hline karwani & & & & & 1 & & & & \\
\hline \multicolumn{10}{|l|}{ maculatus } \\
\hline $\mathrm{A}$ & 9 & 161 & 134 & 134 & 249 & 269 & 303 & 42 & 130 \\
\hline B & 4 & 96 & 42 & 53 & 98 & 122 & 116 & 12 & 6 \\
\hline $\mathrm{G}$ & & & 7 & 23 & 15 & 26 & 25 & 1 & 50 \\
\hline I & & & & & 6 & & & & \\
\hline $\mathrm{H}$ & & & & & 2 & 6 & 47 & 22 & \\
\hline (Total) & 13 & 257 & 183 & 210 & 370 & 423 & 491 & 77 & 186 \\
\hline minimus & 7 & 69 & 51 & 129 & 115 & 50 & 180 & 101 & 65 \\
\hline nivipes & & 30 & 20 & 9 & 63 & 89 & 23 & 12 & 4 \\
\hline peditaeniatus & 58 & 91 & & & 2 & 90 & & 19 & 99 \\
\hline philippinensis & & & 25 & & 55 & & 2 & 3 & \\
\hline ramsayi & & 28 & 76 & 9 & 31 & 7 & 158 & & 21 \\
\hline sinensis & 17 & & & & & & & & \\
\hline tesselatus & & & & 1 & & 3 & 44 & 2 & 1 \\
\hline vagus & 2 & 59 & 8 & 31 & 479 & 309 & 258 & 12 & \\
\hline varuna & 2 & 4 & & & & & 3 & 1 & 1 \\
\hline
\end{tabular}

Identification of An. maculatus: after Rattanarithikul and Green (1986).

Table 3 Parity of two species of anopheline vectors collected from a buffalo bait trap at Ban Tha Lum Yai, during March 1987 to January 1988.

\begin{tabular}{lccccccc}
\hline & Mar. & May & Sept. & Oct. & Nov. & Dec. & Jan. \\
\hline Anopheles minimus & & & & & & & \\
No. exam. & 69 & 51 & 115 & 60 & 347 & 101 & 39 \\
Nulliparous & 8 & 5 & 58 & 23 & 112 & 19 & 7 \\
Parous 1 & 48 & 35 & 55 & 4 & 221 & 82 & 31 \\
Parous 2 & 13 & 11 & 2 & 33 & 14 & 0 & 1 \\
Parous rate & 0.88 & 0.90 & 0.50 & 0.62 & 0.68 & 0.81 & 0.82 \\
\hline Anopheles maculatus & & & & & & & \\
No. exam. & 257 & - & 364 & 423 & 490 & 29 & 61 \\
Nulliparous & 68 & - & 191 & 241 & 196 & 12 & 18 \\
Parous 1 & 145 & - & 153 & 171 & 269 & 16 & 41 \\
Parous 2 & 44 & - & 20 & 11 & 25 & 1 & 2 \\
Parous rate & 0.74 & - & 0.48 & 0.43 & 0.60 & 0.59 & 0.70 \\
\hline
\end{tabular}

Parity was examined following the method of Detinova (1962). 
Table 4 Number of Anopheles collected with human and domestic animal bait traps, in January 1988.

\begin{tabular}{lcccccc}
\hline \hline \multirow{2}{*}{ Anopheles } & Bait of traps & Human & Buffalo & Dog & Hamster & Chicken \\
\cline { 2 - 7 } & Number of trap & 2 & 2 & 2 & 2 & 2 \\
\hline aconitus & & & 1 & & & \\
barbirostris & & 2 & & & \\
kochi & 6 & 10 & & & \\
maculatus & 29 & 78 & 1 & 2 & \\
minimus & & & 45 & & & \\
peditaeniatus & & 1 & & & \\
ramsayi & & & & & & \\
\hline
\end{tabular}

Table 5 Number of Anopheles collected with a human bait trap (two men two consecutive nights) at Ban Tha Lum Yai, Kanchanaburi, during September 1987-January 1988.

\begin{tabular}{lrrrrr}
\hline \hline Species & Sept. & Oct. & Nov. & Dec. & Jan. \\
\hline An. maculatus & & & & & \\
A & 22 & 46 & 17 & 1 & 6 \\
B & 4 & 5 & 6 & 1 & 3 \\
G & 8 & 1 & 5 & 0 & 5 \\
(Total) & 34 & 52 & 28 & 2 & 14 \\
An. minimus & 45 & 26 & 39 & 36 & 24 \\
\hline
\end{tabular}

Identification of $A n$. maculatus: after Rattanarithikul and Green (1986).

Table 6 Number of mosquitoes responding to various systems of traps in March and August 1987.

\begin{tabular}{lccccccccc}
\hline Type of systems & D & H & S & D + H & D + S & S +H & D+H+S & Buffalo & Human \\
\hline No. of trap & 4 & 4 & 4 & 4 & 4 & 4 & 4 & 2 & 2 \\
March* & 0 & 0 & 0 & 5 & 6 & 3 & 64 & 107 & 18 \\
August* & 3 & 1 & 2 & 17 & 9 & 5 & 118 & 339 & 41 \\
\hline
\end{tabular}

* This experiment was performed for a relatively lower population in March and a higher population in August. $\mathrm{D}$, dry ice; $\mathrm{H}$, hamster; $\mathrm{S}$, cage-type trap emitting $530 \mathrm{~Hz}$ of wingbeat sound.

or cylinder type) was tested on females of two species, An. maculatus and An. minimus. Table 7 shows that the sound trap of the cage type was more effective to attract female An. minimus and An. maculatus. The results proved that females of the two species were attracted more to the cage type emitting some preferable range of frequency of sound.

The sound trap of the cage type combined with dry ice and a hamster caught a number of female mosquitoes from March 1987 to January 1988 (Tables 8 and 9). An. minimus was abundantly collected by the trap emitting sound frequencies between 500 and $600 \mathrm{~Hz}$ and between 800 to $1,000 \mathrm{~Hz}$. At $700 \mathrm{~Hz}$ they were trapped in lower numbers; this tendency was also indicated in Table 7. An. maculatus was trapped in a wider range of frequencies, though the catch was lower in number.

\section{Discussion}

In order to develop and improve the technical aspect of field survey and researches on malaria, and to utilize background infor- 
Table 7 Number of female mosquitoes collected with two types of trapping systems emitting various sound frequencies.

\begin{tabular}{cccccccc}
\hline \multirow{2}{*}{ Frequency $(\mathrm{Hz})$} & \multicolumn{3}{c}{ An. minimus } & & \multicolumn{3}{c}{ An. maculatus } \\
\cline { 2 - 7 } & Cylinder & Cage & Total & & Cylinder & Cage & Total \\
\hline 350 & 0 & 12 & 12 & 0 & 0 & 0 \\
400 & 6 & 7 & 13 & 0 & 2 & 2 \\
500 & 7 & 19 & 26 & 0 & 3 & 3 \\
600 & 3 & 16 & 19 & 0 & 2 & 2 \\
700 & 3 & 4 & 7 & 0 & 3 & 3 \\
800 & 6 & 29 & 35 & 0 & 2 & 2 \\
1,000 & 4 & 16 & 20 & 0 & 3 & 3 \\
Soundless* & 3 & 2 & 5 & 0 & 0 & 0 \\
\hline
\end{tabular}

* The trap combined with a hamster and dry ice without sound emitting.

Table 8 Number of female An. minimus collected with a sound cage trap emitting various sound frequencies and combined with a hamster and dry ice, from March 1987 to January 1988.

\begin{tabular}{cccccccccc}
\hline $\begin{array}{c}\text { Frequency } \\
(\mathrm{Hz})\end{array}$ & Mar. & May & Aug. & Sept. & Oct. & Nov. & Dec. & Jan. \\
\hline 500 & $6^{*}(1.5)$ & $8(1.0)$ & $10(1.3)$ & $67(8.4)$ & $24(3.0)$ & $43(5.4)$ & $13(1.6)$ & $24(3.0)$ \\
600 & $8^{*}(2.0)$ & 0 & $9(1.1)$ & $116(14.5)$ & $53(6.6)$ & $36(4.5)$ & $19(2.4)$ & $77(9.6)$ \\
700 & 0 & 1 & $(0.1)$ & $4(0.5)$ & $38(4.8)$ & $57(7.1)$ & $28(3.5)$ & $5(0.6)$ & 0 \\
800 & $14^{*}(3.5)$ & 0 & $18(2.2)$ & $213(26.6)$ & $449(56.1)$ & $217(27.1)$ & $37(4.6)$ & $50(6.3)$ \\
1,000 & $11^{*}(2.8)$ & $5^{*}(1.2)$ & $6(0.8)$ & $207^{*}(51.8)$ & $228^{*}(57.0)$ & $182^{*}(45.5)$ & $20^{*}(5.0)$ & $50(6.3)$ \\
Control & $6(0.8)$ & 1 & $10.1)$ & 0 & $18(2.3)$ & $102(12.8)$ & $69(8.6)$ & $16(2.0)$ & 0 \\
\hline
\end{tabular}

Average number of mosquitoes per trap was shown in the parenthesis. Four (* marked) or eight traps were used in the tests and soundless trap with a hamster and dry ice in a cage was used as control.

Table 9 Number of female $A n$. maculatus collected with sound cage trap emitting various sound frequencies and combined with a hamster and dry ice, from May 1987 to January 1988.

\begin{tabular}{|c|c|c|c|c|c|c|c|}
\hline $\begin{array}{l}\text { Frequency } \\
(\mathrm{Hz})\end{array}$ & May & Aug. & Sept. & Oct. & Nov. & Dec. & Jan. \\
\hline 500 & 0 & $3(0.4)$ & $6(0.8)$ & $1(0.1)$ & $10(1.3)$ & $4(0.5)$ & $10(1.3)$ \\
\hline 600 & 0 & $2(0.3)$ & $20(2.5)$ & $6(0.8)$ & $28(3.5)$ & $5(0.6)$ & $11(1.4)$ \\
\hline 700 & $1^{*}(0.3)$ & $4(0.5)$ & $14(1.8)$ & $2(0.3)$ & $10(1.3)$ & $3(0.4)$ & $9(1.1)$ \\
\hline 800 & $1^{*}(0.3)$ & $8(1.0)$ & $12(1.5)$ & $47 \quad(5.9)$ & $52(6.5)$ & $8(1.0)$ & $31 \quad(3.9)$ \\
\hline 1,000 & 0 & $5(0.6)$ & $12^{*}(3.0)$ & $38 *(9.5)$ & $47^{*}(11.8)$ & $2^{*}(0.5)$ & $14(1.8)$ \\
\hline Control & 0 & 0 & 0 & $12(1.5)$ & $19(2.4)$ & 0 & 0 \\
\hline
\end{tabular}

Average number of mosquitoes per trap was shown in the parenthesis. Four (* marked) or eight traps were used in the tests and soundless trap with a hamster and dry ice in a cage was used as control.

mation on future control project, malariometric investigation and vector surveys were first carried out. The malaria parasite rate in the study area remained high in 1986-1987 (Table 1). This result suggests that perennial stable malaria has been endemic in this village. In addition, high to holoendemicity of malaria in this village according to data of the Malaria Division, Ministry of Public Health (Malaria Division, 1986.1987) supports the present results of high parasite rate. Despite the low density of the vector popula- 
tions, their high parous rates might be thought to support the stability of malaria transmission in the area. The decrease of parous rate from September to November might be due to increase of mosquito density by newly emerged females, as monitored by the buffalo bait (Table 2) and also by sound trapping (Tables 8 and 9). The high-risk situation of malaria endemicity in this village underlines the urgency to implement malariometric and vector surveys, and malaria control in this area.

The human bait method can effectively monitor the mosquito population, but its use in field operation is controversial because of the hazards to man. On the other hand, sound trapping emitting animal scent and evaporating $\mathrm{CO}_{2}$ from dry ice produced parallel fluctuation of population density derived from results of both human and buffalo baits which were performed monthly and seasonally. Moreover, the number of mosquitoes collected by this trapping system was 3 to 4 times larger than that collected with human bait, though it was $1 / 3$ to $1 / 4$ of that collected with buffalo bait. These facts proved the effectiveness of this trapping system not only for monitoring the fluctuation of mosquito population but also in terms of protection of malaria workers from malaria infection. When this sound trap system is used, the blood meal preference of vectors which is epidemiologically required may not be analyzed. This problem can, however, be solved by other ways such as the precipitin test of the vectors collected.

$A n$. minimus was highly attracted to sound traps with frequencies from 500 to $600 \mathrm{~Hz}$ and from 800 to $1,000 \mathrm{~Hz}$. This phenomenon may be due to the difference of their mating behavior, and some genetic divergence may ethologically exist. The details of this ethological phenomenon will be published in a separate paper. The differences of wing-beat frequency within various colonies and members of a given species and among different taxa were proved by Kanda et al. (1986) and Ogawa and Kanda (1986). According to measurements of wing-beat frequency, members of the An. minimus group showed slightly different frequencies. In An. minimus s.s., females showed $464.8 \pm 7.6 \mathrm{~Hz}$ (mean \pm S.E.), whereas males $713.1 \pm 22.4 \mathrm{~Hz}$. In $A n$. mini- mus pampanai type, female showed 473.0 $\pm 5.2 \mathrm{~Hz}$, whereas males $709.5 \pm 10.5 \mathrm{~Hz}$. As far as the present result obtained from one of the anopheline species is concerned, this seems to show the genetic divergence relating to several other biological characteristics in the phylogeny of this species group (Kanda et al., 1984; Sucharit et al., 1986; Komalamisra, 1989). On the other hand, An. maculatus was trapped in a more limited range of sound frequency. This may suggest the species in this village consisted of either one group or many (Table 5). In the previous experiment (Kanda et al., 1986), An. maculatus showed much intertaxonomic variability in their wingbeat sound frequencies.

The biting preference test of these two vectors and other anopheline species proved that the vectors fed preferably on buffalo and human baits, but not on dog or chicken (Tables 2, 4 and 5). Hamster was experimentally an efficient blood donor, although the efficiency was one-third of human bait. Buffalo was a good blood donor to all anopheline species in the area. Despite the fact that human was a tentative or partial donor compared to buffalo in the village, human malaria transmission has been stably maintained.

Possible utilization of this trapping system arises as one means of future control of the vectors. If buffalos were protected from the anopheline's biting, density of this species would be greatly reduced, though some ethological changes may occur, especially in their biting activity for a while.

\section{Acknowledgements}

Sincere gratitude is extended to Dr. Masamichi Fujii, President of St. Marianna University, for the promotion of the scientific researches project of the university for Dissertation Ph.D. and research support for this study in Thailand as advisor, Dr. Tozo Kanda for his supervision of this project. Thanks is also extended to Associate Professor Dr. Supat Sucharit, Head of Department of Medical Entomology, Faculty of Tropical Medicine and Mr. Kamhang Suratint, and the staffs of the Department of Medical Entomology, Faculty of Tropical Medicine, Mahidol University and Department of Medical Zoology, St. Marianna University. I thank Dr. Toshiaki Ikeshoji, Professor, Faculty of Agriculture, the University of Tokyo, for his reading of the manuscript and suggested 
revisions.

\section{REFERENCES}

Detinova, T. S. (1962): Age grouping methods in Diptera of medical importance with special reference to some vectors of malaria. $W . H . O$. Mongr. Ser., No. 47: 1-216.

Ikeshoji, T. (1985): Age structure and mating status of the male mosquitoes responding to sound. Jpn. J. Sanit. Zool., 36: 95-101.

Ikeshoji, T., M. Sakakibara and W. K. Reisen (1985): Removal sampling of male mosquitoes from field population by sound-trapping. Jpn. J. Sanit. Zool., 36: 197-203.

Ismail, I. A. H. (1983) : Malaria control in South East Asia: The integrated approach and research needs. In: Conference on Malaria Research, 21-30, Malaria Division, Ministry of Public Health, Thailand.

Kanda, T. (1979): Improved techniques for the preparation of polytene chromosomes for some anopheline mosquitoes. Mosq. News, 39: 568574.

Kanda, T., W. H. Cheong, K. P. Loong, T. W. Lim, K. Ogawa, G. L. Chiang and S. Sucharit (1987): Collection of male mosquitoes from field populations by sound trapping. Trop. Biomed., 4: 161-166.

Kanda, T., K. P. Loong, G. L. Chiang, W. H. Cheong and T. W. Lim (1988): Field study on sound trapping of Mansonia in Malaysia: 2. Development of trapping method for both sexes. Trop. Biomed., 5: 37-42.

Kanda, T., K. Ogawa, S. Sucharit, G. L. Chiang and C. Harinasuta (1984): Cytogenetic and hybridization studies among three strains morphologically variational and belonging to Anopheles minimus Theobald from Japan and Thailand. Cytologia, 49: 865-881.

Kanda, T., K. Ogawa and K. Takai (1986): Intertaxonomic variability of wingbeat frequency among sibling taxa within some anopheline species groups in East Asia. Jpn. J. Sanit. Zool., 37: 385-387.

Komalamisra, N. (1989): Genetic variability in isozymes of Anopheles minimus group from various localities in Thailand. Jpn. J. Sanit. Zool., 40: 69-80.

Leemingsawat, S., V. Kerdpibule, S. Limswan, S. Sucharit, K. Ogawa and T. Kanda (1988): Response of female mosquitoes of Culex tritaeniorhynchus to sound traps of various wingbeat frequencies with hamster and dry ice. Jpn. J. Sanit. Zool., 39: 67-70.

Malaria Division (1985): Annual Report of Ministry of Public Health, 125 pp., Ministry of Public Health, Thailand.
Malaria Division (1986-1987): Annual Report of Ministry of Public Health, 158 pp., Ministry of Public Health, Thailand.

Ogawa, K. and T. Kanda (1986): Wingbeat frequencies of some anopheline mosquitoes of East Asia (Diptera: Culicidae). Appl. Entomol. Zool., 21 : 430-435.

Rattanarithikul, R. and C. A. Green (1986): Formal recognition of the Anopheles maculatus (Diptera: Culicidae) occurring in Thailand, including the descriptions of two new species and a preliminary key to females. Mosq. Syst., 18: 246-277.

Sucharit, S., N. Komalamisra, C. Apiwathanasorn, S. Limsuwan and S. Leemingsawat (1986): Anopheles minimus species complex in Thailand. In: Second Conference on Malaria Research, Malaria Division, 148 pp., Ministry of Public Health, Thailand.

Sucharit, S. and S. Supavej (1987): Practical entomology of malaria and filariasis. In: $M R C$ TROPMED Publication, 199 pp., Faculty of Tropical Medicine, Mahidol Lniversity, Bangkok.

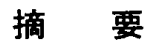

タイ国カンチャナブリ省山麓地帯渓谷での マラリアの疫学的研究と種々トラップ法による 媒介ハマダラカ捕獲の試み

タイ国カンチャナブリ省, 山麓渓谷に沿う山村マラ リア流行地夕・ラム・ヤイ村において，媒介蚊の消長 と，マラリア原虫検出状況を検討し，また，ヒトや動 物をおとりにした吸血採集法と羽音による音響捕獲法 との有効性を比較検討した，吸血採集では，水牛をお とりにした場合に最む多くのハマダラカ類が採れ，16 種に及んだ。ヒトを吸血したのはそのうちの 2 種で, An. minimus は水牛の場合のほぼ $1 / 4, A n$. maculatus は $1 / 3$ が採集され，その他の動物では同じくこ れら 2 種が採れたが，数ははるかに少なかった。この ことからヒトのマラリアの媒介蚊はこれら 2 種が主役 をなし，おもに水牛を吸血して繁殖しているものと推 测された。経産蚊率は両種とも高く minimus は 9 月 の0.5が最低，5月の0.9が最高， maculatus は10月 の 0.43 が最低, 3 月の 0.74 が最高という值を示し, マラリアの高度安定流行に関与しているとみられた。 これら 2 種は音響トラップに著明に応答し，ドライア イスとハムスターを併用した場合に，捕獲が促進され た. しかもヒト吸血の 3 倍を捕獲し年間の消長のモ二 タリングに，ヒトおとり吸血に代わり有用と思われ た.なお，種群内に異なった振動数に态答するものが みられ, minimus 群では $500 \sim 600 \mathrm{~Hz}$ に応答するも のと，800 1, $000 \mathrm{~Hz}$ に応答する 2 集団が別れて捕獲 された.これに対し maculatus 群では，各振動数の音 響に一様にそれぞれ応答する雌ハマダラカを採集し た.このことは遺伝的分化との関連を示唆するものと 考えられた。 